\title{
A case of heparin-induced thrombocytopenia (HIT) triggered by methicillin-susceptible Staphylococcus aureus (MSSA) bacteremia
}

Sayaka Sugioka ${ }^{1}$, Yohei Doi ${ }^{*}$, Takeshi Ishihara ${ }^{2}$, Tetsuya Arisato ${ }^{1}, K^{\prime}$ Keisuke Osaki ${ }^{1}$, Kenichi Koga ${ }^{1}$, Masao Koshikawa' and Akira Sugawara ${ }^{1}$

\begin{abstract}
Background: Heparin-induced thrombocytopenia (HIT) is a potentially life-threatening complication of heparin anticoagulation. Recently, infection has been implicated in the development of HIT.

Case presentation: We herein present a case of HIT diagnosed by a repeated functional assay. A 67-year-old female with diabetic nephropathy was admitted to our hospital with hypoxemia caused by volume overload. Due to her diuretic-resistant condition, dialysis therapy anticoagulated with low-molecular-weight heparin (LMWH) was initiated. The coagulation of the whole extracorporeal blood circuit occurred on day 13. Methicillin-susceptible Staphylococcus aureus (MSSA) bacteremia derived from a catheter-related bloodstream infection (CRBSI) was detected on day 15. Based on the hypercoagulable state due to infection, we increased the heparin dose during dialysis therapy; however, coagulation of the dialysis circuit persisted. We suspected HIT on day 17 in spite of a normal platelet count and performed a functional assay, which was negative. Since thrombocytopenia subsequently developed, the functional assay was repeated and a positive result was obtained on day 27 , which definitely established a diagnosis of HIT.
\end{abstract}

Conclusions: Based on the present clinical course, MSSA bacteremia appears to have contributed to the pathogenesis of HIT.

Keywords: HIT, Functional assay, Antigen assay, Hypercoagulable state, MSSA bacteremia

\section{Background}

Heparin-induced thrombocytopenia (HIT) is a potentially critical complication of heparin therapy which results in thromboembolism. The HIT antibody test is frequently used to make a diagnosis. However, due to the relatively high rate of false-positive results, careful evaluations of clinical features and laboratory examinations are necessary. Therefore, a diagnosis of HIT is challenging, and the availability of functional assays is indicated. We herein present a case of HIT triggered by MSSA bacteremia. A functional assay exhibited the ability to explain the

\footnotetext{
* Correspondence: ydoi@osaka-med.jrc.or.jp

'Department of Nephrology, Osaka Red Cross Hospital, Osaka, Japan

Full list of author information is available at the end of the article

complex pathophysiology and interpret the relationship between HIT and infection.

\section{Case presentation}

A 67-year-old female with a previous medical history of diabetic nephropathy was referred to our hospital with progressive shortness of breath. Her medical history included type 2 diabetes mellitus, hypertension, and dyslipidemia, but no history of heparin administration. Her medication regimen consisted of amlodipine $10 \mathrm{mg}$, cilnidipine $20 \mathrm{mg}$, telmisartan $80 \mathrm{mg}$, furosemide $60 \mathrm{mg}$, rosuvastatin $5 \mathrm{mg}$, and febuxostat $20 \mathrm{mg}$ per day. She was afebrile and hemodynamically stable. She had tachypnea and $\mathrm{SpO} 2$ in room air was $74 \%$. A physical examination revealed a gallop rhythm, wheezing on chest auscultation, 
and prominent pitting edema on the legs. Chest X-ray showed the marked enlargement of a cardiac shadow and bilateral pleural effusion. Laboratory tests revealed severe renal impairment, and her platelet count (Plt) was normal at $232,000 / \mu \mathrm{l}$ (Table 1). We diagnosed the patient as having respiratory failure due to volume overload, and an intravenous bolus injection of furosemide $100 \mathrm{mg}$ was administered with no effect. A drip infusion of carperitide and oral tolvaptan at $15 \mathrm{mg} /$ day were added. However, since her condition did not improve, hemodialysis (HD) therapy anticoagulated with $\mathrm{LMWH}$ was initiated on day 3 (Plt 220,000/ $\mu \mathrm{l}$, the first day of heparin exposure) through the dialysis catheter in the right internal jugular vein. During non-dialysis periods, the catheter cavity was locked with unfractionated heparin (UFH). After the initiation of HD, dyspnea gradually resolved, whereas renal dysfunction worsened. On day 13, the blood circuit of HD

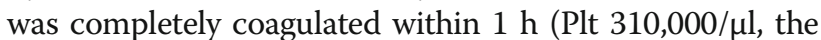
11th day of heparin exposure). Since she became febrile on day 15, empirical intravenous vancomycin for catheterrelated bloodstream infection (CRBSI) was started. CRBSI was established based on the positive results of a blood culture for MSSA. On day 16, she developed back pain. Lumbar MRI revealed pyogenic spondylitis due to CRBSI. On day 16 , the dialysis circuit was completely coagulated just after the initiation of HD. On the same day, the dialysis catheter in the right jugular vein was removed for

Table 1 Laboratory data

\begin{tabular}{ll}
\hline CBC & \\
WBC & $5930 / \mu l$ \\
RBC & $320 \times 10^{4} / \mu l$ \\
$\mathrm{Hb}$ & $9.1 \mathrm{~g} / \mathrm{dl}$ \\
$\mathrm{Hct}$ & $29.0 \%$ \\
Plt & $23.2 \times 10^{4} / \mu \mathrm{l}$ \\
Chemistry & \\
CRP & $0.2 \mathrm{mg} / \mathrm{dl}$ \\
TP & $6.7 \mathrm{~g} / \mathrm{dl}$ \\
ALB & $3.9 \mathrm{~g} / \mathrm{dl}$ \\
GOT & $13 \mathrm{IU} / \mathrm{l}$ \\
GPT & $11 \mathrm{IU} / \mathrm{l}$ \\
Glu & $134 \mathrm{mg} / \mathrm{dl}$ \\
$\mathrm{Na}$ & $142 \mathrm{mEq} / \mathrm{l}$ \\
$\mathrm{K}$ & $4.3 \mathrm{mEq} / \mathrm{l}$ \\
$\mathrm{Cl}$ & $108 \mathrm{mEq} / \mathrm{l}$ \\
Ca & $8.2 \mathrm{mg} / \mathrm{dl}$ \\
P & $5.4 \mathrm{mg} / \mathrm{dl}$ \\
BUN & $55.9 \mathrm{mg} / \mathrm{dl}$ \\
Cre & $4.16 \mathrm{mg} / \mathrm{dl}$ \\
UA & $7.4 \mathrm{mg} / \mathrm{dl}$ \\
\hline
\end{tabular}

CRBSI. The complete coagulation of the dialysis circuit on days 13 and 16 was attributed to the hypercoagulable state derived from infection and not by HIT due to the normal platelet count. A new dialysis catheter was placed in the left internal jugular vein because right internal jugular vein thrombosis was detected. A UFH of $10,000 \mathrm{U} / 24 \mathrm{~h}$ was administrated systemically against right internal jugular vein thrombosis. On day 17 , the complete coagulation of the dialysis circuit was detected though the systemic administration of UFH and an intravenous bolus (750 U) of continuous LMWH (450 U/h) for HD. Because the case in which manifestation of HIT-related thrombosis prior to a decrease in the platelet count is reported, all forms of heparin including the locking of the dialysis catheter lumen were stopped on day 20. On day 21, HD was accomplished through anticoagulation with nafamostat mesilate. HIT was strongly suspected, and the systemic administration of adjusted argatroban was initiated. On day 23, a positive result for the HIT antigen assay (latex agglutination assay) was obtained for a blood specimen collected on day 17 (optical density $2.0 \mathrm{U} / \mathrm{ml}$, normal $<1 \mathrm{U} / \mathrm{ml}$ ). In order to make a definite diagnosis, blood specimens on day 17 (15th day after exposure to heparin) and day 27 (25th day after exposure to heparin) were examined by a functional assay (washed platelet activation assay) [1], and a negative result was obtained for the specimen collected on day 17 , whereas the result was positive for that on day 27. The platelet count normalized to $170,000 / \mu \mathrm{l}$, and warfarin was added to argatroban on day 28. There was no sign of thrombosis, except for thrombus in the right internal jugular vein. Renal dysfunction improved slowly following the withdrawal of HD therapy. Regarding pyogenic spondylitis, cefazolin and minomycin were administered 8 weeks after the confirmation of a negative blood culture result.

\section{Discussion}

HIT is a thrombotic immune-mediated response to $\mathrm{UFH}, \mathrm{LMWH}$, and other polyanions [2]. Regarding the mechanisms underlying the development of HIT, platelet factor 4 (PF4) is released on the platelet membrane and into the bloodstream from the alpha granules of platelets. PF4 is positively charged and may combine with administered heparin to form a PF4/heparin complex. This complex was previously reported to be formed in vitro at molar ratios of heparin to PF4 of 1:1 to 1:4 [3, 4].

The PF4/heparin complex is recognized as an antigen, and a PF4/heparin complex antibody (HIT antibody) is produced, which forms an immune complex with the PF4haparin complex; the Fc region of the HIT antibody combines with the Fcylla receptor on the platelet membrane, which activates platelets and induces thrombocytopenia [5]. A previous study reported that IgM, IgA, and IgG were almost simultaneously elevated around the fifth day after the 
exposure of HIT patients to heparin; however, only IgG exhibited an activation capacity for platelets, monocytes, and vascular endothelial cells and may be involved in the pathogenesis of HIT [6]. In the case of intrinsic immune responses, IgM is produced, a class switch is then stimulated, and IgG increases 2 weeks later; therefore, the HIT IgG response is considered to be atypical [7]. The production of pathogenic HIT IgG has been proposed as a misdirection of the immune defense system against negatively charged microorganisms. When bacterial infection occurs in the human body, platelets are activated and release positively charged PF4. PF4 binds charge dependently to various bacteria including Staphylococcus aureus [8]. Especially in gram-negative bacteria, PF4 combines with lipid A and forms a PF4/bacteria complex [9]. Also PF4 binds to nucleic acids generated from breakdown of bacteria and viruses, tissue damage, cell apoptosis, and the release from blood cells such as the formation of neutrophil extracellular traps [10]. IgG against the PF4/bacteria complex has a defensive function such as the promotion of opsonization against bacteria and also combines with the PF4/heparin complex. In other words, when bacterial infection occurs, a PF4/bacteria complex similar to the PF4/heparin complex is formed, thereby exposing the PF4/heparin-like epitope recognized by antibodies which is induced in patients during heparin treatments. This theory may explain the formation of HIT IgG after approximately 5 days in the early period. In rare cases, HIT was recently shown to develop incidentally among patients with no history of heparin administration [8]. These patients had auto-immune diseases such as SLE and/or recent microbial infection.

HIT is diagnosed by integrating clinical features and the results of laboratory examinations. The 4Ts score is typically utilized in a clinical diagnosis (Table 2) [11]. The 4Ts score has a prior requirement of thrombocytopenia; however, a previous study reported that $25 \%$ of HIT patients developed thrombosis 1 to 2 days earlier than thrombocytopenia [12], and its positive predictive value was relatively low [13]. Antigen and functional assays are used to make the serological diagnosis of HIT. The antigen assay measures an antigen of the PF4/heparin complex and PF4/heparin antibody levels. Although antigen assay is highly sensitive, its specificity is limited by the detection of HIT IgG in patients who do not have HIT or non-pathogenic IgM or IgA [14]. The optimal density (OD) values of enzyme immunoassays may be used to increase specificity; when the OD value is markedly higher than the cut-off value, the possibility of HIT is high [15]. A functional assay is more specific than an enzyme immunoassay for clinically relevant antibodies (capability of activating platelets), but is not widely available. Functional assays exhibit excellent sensitivity and specificity $[16,17]$.

In the present case, when the hypercoagulable state was observed, a negative functional assay result, slightly positive OD value, and the absence of accompanying thrombocytopenia essentially ruled out HIT on day 17 (15 days after exposure to heparin). The cause of the hypercoagulable state may have been CRBSI by MSSA. A HIT functional assay conducted on day 27 (25 days after exposure to heparin) was positive, resulting in a definite diagnosis of HIT. We consider HIT to have developed around day 21 (19th day of exposure to heparin) because thrombocytopenia was retrospectively observed in that period (Fig. 1). Since HIT typically develops 5 to 14 days after the administration of heparin, its onset was slightly later in the present case. MSSA bacteremia may have played a role in this discrepancy in latency. In spite of the administration of heparin, the pathogenic antigen of the PF4/heparin complex was not present; MSSA bacteremia triggered exposure of the pathogenic antigen through mechanisms such as the activation of platelets, a change in the PF4/heparin ratio, and the formation of the MSSA/PF4 complex. This hypothesis may explain why a diagnosis of HIT was established approximately 1 week after MSSA bacteremia. And this hypothesis is similar to the mechanism of "resetting the clock", in which HIT may develop independently of the typical time frame following recent catheter or surgical interventions [18]. For example, a previous study reported

Table 2 HIT 4Ts score

\begin{tabular}{|c|c|c|c|}
\hline 4Ts category & 2 points & 1 points & 0 points \\
\hline Thrombocytopenia & $\begin{array}{l}\text { Platelet count decrease }>50 \% \\
\text { and platelet nadir }>20 \times 10^{9} \mathrm{~L}^{-1}\end{array}$ & $\begin{array}{l}\text { Platelet count decrease } 30-50 \% \\
\text { or platelet nadir } 10-19 \times 10^{9} \mathrm{~L}^{-1}\end{array}$ & $\begin{array}{l}\text { Platelet count decrease }<30 \% \\
\text { or platelet nadir }<10 \times 10^{9} \mathrm{~L}^{-1}\end{array}$ \\
\hline $\begin{array}{l}\text { Timing of the platelet } \\
\text { count decrease }\end{array}$ & $\begin{array}{l}\text { Clear onset days } 5-10 \text { or platelet } \\
\text { decrease }<1 \text { day (prior heparin } \\
\text { exposure within } 30 \text { days) }\end{array}$ & $\begin{array}{l}\text { Consistent with the day } 5-10 \text { decrease, } \\
\text { but not clear; onset after day } 10 \text {, } \\
\text { or decrease }<1 \text { day (prior heparin } \\
\text { exposure } 30-100 \text { days ago) }\end{array}$ & $\begin{array}{l}\text { Platelet count decrease }<4 \text { days } \\
\text { without recent heparin exposure }\end{array}$ \\
\hline $\begin{array}{l}\text { Thrombosis or other } \\
\text { sequelae }\end{array}$ & $\begin{array}{l}\text { New thrombosis (confirmed); } \\
\text { skin necrosis; acute systemic } \\
\text { reaction to the post-intravenous } \\
\text { unfractionated heparin bolus }\end{array}$ & $\begin{array}{l}\text { Progressive or recurrent thrombosis; } \\
\text { non-necrotizing (erythematous) } \\
\text { skin lesions; suspected thrombosis } \\
\text { (not proven) }\end{array}$ & None \\
\hline $\begin{array}{l}\text { Other causes of } \\
\text { thrombocytopenia }\end{array}$ & None apparent & Possible & Definite \\
\hline
\end{tabular}




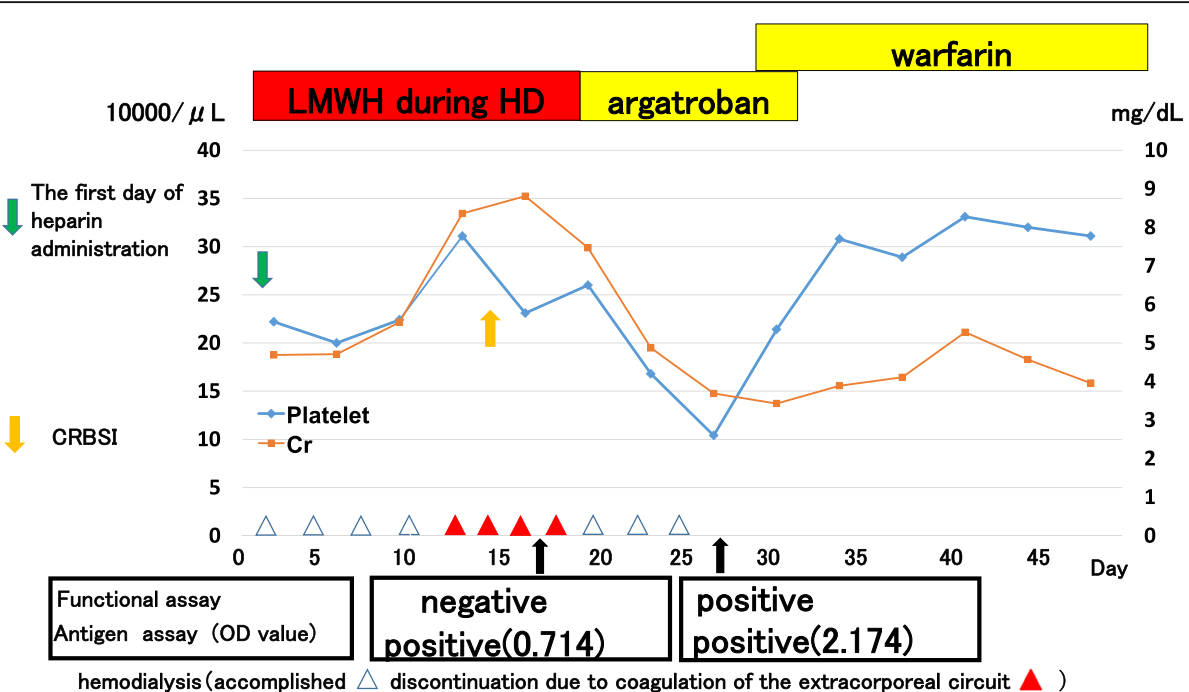

Fig. 1 Clinical course

that a patient receiving dialysis therapy for 9 years developed HIT for the first time 5 14 days after surgery [19]. Therefore, more PF4 and nucleic acid may be released from platelets and damaged tissues due to catheter or surgical interventions, resulting in changes in the PF4/ heparin ratio and/or form PF4/nucleic acid complexes, which predisposes a patient to HIT.

\section{Conclusions}

We encountered a case of HIT diagnosed by a repeated functional assay. Recent advances have been achieved in understanding the pathophysiology of HIT, particularly in the relationship between HIT and infection. To the best of our knowledge, this is the first case report to focus on the relationship between infection and the development of HIT, as proven using a repeated functional assay.

\section{Abbreviations}

CRBSI: Catheter-related bloodstream infection; HD: Hemodialysis:

HIT: Heparin-induced thrombocytopenia; LMWH: Low-molecular-weight heparin; MSSA: Methicillin-susceptible Staphylococcus aureus; OD: Optimal density; PF4: Platelet factor 4; PIt: Platelet count; UFH: Unfractionated heparin

\section{Acknowledgements}

We are grateful to Dr. Takuma Maeda and Dr. Shigeki Miyata (National Cerebral and Cardiovascular Center, Japan) for performing the functional assay to diagnose HIT.

\section{Funding}

The authors declare that they did not receive any funding.

\section{Availability of data and materials}

The data sets supporting the conclusions of this report are included within the article.

\section{Authors' contributions}

SS wrote the initial draft. YD and AS contributed to the critical revision. SS, YD, $\mathrm{TI}, \mathrm{TA}, \mathrm{KO}, \mathrm{MK}$, and $\mathrm{AS}$ contributed to the interpretation of the pathological condition. All authors read and approved the final version of the manuscript.

\section{Authors' information}

Sayaka Sugioka: Clinical Fellow of the Department of Nephrology

Yohei Doi: Clinical Fellow of the Department of Nephrology

Takeshi Ishihara: Chief of the Department of Clinical Engineering

Tetsuya Arisato: Resident of the Department of Nephrology

Keisuke Osaki: Clinical Fellow of the Department of Nephrology

Masao Koshikawa: Assistant director of the Department of Nephrology

Akira Sugawara: Director of the Department of Nephrology.

\section{Competing interests}

The authors declare that they have no competing interests.

\section{Consent for publication}

Written informed consent was obtained from the patient for the publication of this case report and any accompanying images.

Ethics approval and consent to participate

Based on the Ethical Guidelines for Medical and Health Research Involving Human Subjects in Japan, Ethics approval is not necessary when submitting case reports.

\section{Author details}

'Department of Nephrology, Osaka Red Cross Hospital, Osaka, Japan.

${ }^{2}$ Department of Clinical Engineering, Osaka Red Cross Hospital, Osaka, Japan.

Received: 9 May 2016 Accepted: 21 October 2016

Published online: 08 December 2016

\section{References}

1. Maeda T, Noguchi T, Saito S, Yoshioka R, Horibe E, Miyanaga S, et al. Impact of heparin-induced thrombocytopenia on acute coronary artery thrombosis in patients undergoing PCI. Thromb Haemost. 2014;112:624-6.

2. Warkentin TE, Greinacher A, Koster A, Lincoff AM. Treatment and prevention of heparin-induced thrombocytopenia. American College of Chest Physicians Evidence-Based Clinical Practice Guidelines (8th Edition). Chest. 2008;133(6 Suppl):340S-80.

3. Greinacher A, Gopinadhan M, Gunther JU, Omer-Adam MA, Strobel U, Warkentin TE, et al. Close approximation of two platelet factor 4 tetramers by charge neutralization forms the antigens recognized by HIT antibodies. Arterioscler Thromb Vasc Biol. 2006:26:2386-93.

4. Rauova L, Poncz M, McKenzie SE, Reilly MP, Arepally G, Weisel JW, et al. Ultralarge complexes of PF4 and heparin are central to the pathogenesis of heparin-induced thrombocytopenia. Blood. 2005;105:131-8.

5. Reilly MP, Taylor SM, Hartman NK, Arepally GM, Sachais BS, Cines DB, et al. Heparin-induced thrombocytopenia/thrombosis in a transgenic mouse 
model requires human platelet factor 4 and platelet activation through FcyRllA. Blood. 2001;98:2442-7.

6. Warkentin TE, Sheppard JA, Moore JC, Cook RJ, Kelton JG. Studies of the immune response in heparin-induced thrombocytopenia. Blood. 2009;113:4963-9.

7. Greinacher A, Kohlmann T, Strobel U, Sheppard JA, Warkentin TE. The temporal profile of the anti-PF4/heparin immune response. Blood. 2009;113:4970-6.

8. Krauel K, Potschke C, Weber C, Kessler W, Furll B, Ittermann T, et al. Platelet factor 4 binds to bacteria-inducing antibodies cross-reacting with the major antigen in heparin-induced thrombocytopenia. Blood. 2011;117:1370-8.

9. Krauel K, Weber C, Brandt S, Zahringer U, Mamat U, Greinacher A, et al. Platelet factor 4 binding to lipid A of Gram-negative bacteria exposes PF4/ heparin-like epitopes. Blood. 2012;120:3345-52.

10. Jaax ME, Krauel K, Marschall T, Brandt S, Gansler J, Furll B, et al. Complex formation with nucleic acids and aptamers alters the antigenic properties of platelet factor 4. Blood. 2013:122:272-81.

11. Lo GK, Juhl D, Warkentin TE, Sigouin CS, Eichler P, Greinacher A. Evaluation of pretest clinical score (4T's) for the diagnosis of heparin-induced thrombocytopenia in two clinical settings. J Thromb Haemost. 2006;4:759-65.

12. Greinacher A, Farner B, Kroll H, Kohlmann T, Warkentin TE, Eichler P. Clinical features of heparin-induced thrombocytopenia including risk factors for thrombosis. A retrospective analysis of 408 patients. Thromb Haemost. 2005; 94:132-5.

13. Cuker A, Gimotty PA, Crowther MA, Warkentin TE. Predictive value of the 4Ts scoring system for heparin-induced thrombocytopenia: a systematic review and meta-analysis. Blood. 2012;120:4160-7.

14. Greinacher A. Heparin-induced thrombocytopenia. N Engl J Med. 2015;373: $1883-4$.

15. Warkentin TE, Sheppard JI, Moore JC, Sigouin CS, Kelton JG. Quantitative interpretation of optical density measurements using PF4-dependent enzyme-immunoassays. J Thromb Haemost. 2008;6:1304-12.

16. Harenberg J, Huhle G, Giese C, Wang LC, Feuring M, Song XH, Hoffmann U. Determination of serotonin release from platelets by enzyme immunoassay in the diagnosis of heparin-induced thrombocytopenia. Br J Haematol. 2000;109:182-6.

17. Lee DH, Warkentin TE, Denomme GA, Hayward CPM, Kelton JG. A diagnostic test for heparin-induced thrombocytopenia: detection of platelet microparticles using flow cytometry. Br J Haematol. 1996:95:724-31.

18. Warkentin TE. Clinical picture of heparin-induced thrombocytopenia. In: Warkentin TE, Greinacher A, editors. Heparin-induced thrombocytopenia. New York: Marcel Dekker; 2000. p. 43-80.

19. Tholl U, Greinacher A, Overdick K, Anlauf M. Life-threatening anaphylactic reaction following parathyroidectomy in a dialysis patient with heparininduced thrombocytopenia. Nephrol Dial Transplant. 1997;12:2750-5.

\section{Submit your next manuscript to BioMed Central and we will help you at every step:}

- We accept pre-submission inquiries

- Our selector tool helps you to find the most relevant journal

- We provide round the clock customer support

- Convenient online submission

- Thorough peer review

- Inclusion in PubMed and all major indexing services

- Maximum visibility for your research

Submit your manuscript at www.biomedcentral.com/submit

CBiomed Central 